\title{
Behind Covid-19: Panic Buying, Service Convenience in Modern Market Indonesia
}

\section{Nourissa Dinda Syachadi', Agatha Christy Avega Dumatri², Muhammad Fajar Wahyudi Rahman ${ }^{3}$, Hujjatullah Fazlurrahman ${ }^{*}$}

1,2,3,4 Department of Management, Faculty of Economics, Universitas Negeri Surabaya, Indonesia

*Corresponding author: hujjatullahfazlurrahman@unesa.ac.id

Article History

Received 2021-02-16

Revised 2021-03-09

Accepted 2021-03-10

Published 2021-03-13

\section{Keywords \\ Indonesia \\ Panic Buying \\ Service Convenience \\ Purchase Decision \\ Consumer Behavior \\ COVID-19}

\section{How to cite?}

Syachadi, N. D., Dumatri, A. C. A., Rahman, M. F. W., \& Fazlurrabman, H. Behind Covid-19: Panic Buying, Service Convenience in Modern Market Indonesia. SEISENSE Journal of Management, 4(2), 45-55. doi:

10.33215/sjom. $24 i 2.584$

\section{Abstract}

Purpose- This study aims to analyze the effect of panic buying and service convenience on consumer purchasing decisions in modern markets such as mini markets, supermarkets, and hypermarkets in Surabaya.

Design/Methodology- This research makes use of a quantitative approach. The object of this research is consumers who shop at grocery stores during the Covid-19 pandemic between March and June 2020 in the city of Surabaya, East Java, Indonesia. Within this research, 84 respondents were used as the sample. The process of collecting the data was conducted through online-based questionnaires. Multiple linear regression analysis with the help of SPSS 23.0 software was used to analyze the research.

Findings- The researchers concluded that all existing hypotheses both $\mathrm{H} 1$ and $\mathrm{H} 2$, were valid. It also showed a significant positive relationship between panic buying, service convenience, and consumer purchasing decision behavior.

Practical Implications- Furthermore, the results stated that the modern market must understand the community's conditions and keep up with the latest situation surrounding customers' needs. 


\section{Introduction}

The Covid-19 pandemic has a profound impact on all domains of our lives. Something uncertain creates very negative emotions, such as fear, panic, and anxiety (Thukral, 2020). Existing anxiety occurs not only because of virus transmission but also because of anxiety in meeting people's basic needs. Several countries reported the phenomena of panic buying as a response to this pandemic. Besides Covid-19, panic buying has also spread throughout the world from Singapore to the United States, reporting long queues at supermarkets for several weeks due to many consumers wanting to buy basic necessities such as rice and hand sanitizers to toilet paper (Thukral, 2020). In Indonesia, after the announcement of two Indonesian citizens infected with Covid-19 in March 2020, people began to make excessive purchases of necessities, hand sanitizers, and masks. These products have been invaded by the people of Jakarta (Putra, 2020).

The Indonesian government imposes Large-Scale Social Restrictions (PSBB) as listed in Government Regulation No. 21 of 2020 (Pemerintah Indonesia, 2020). PSBB regulates restrictions on activities in public places or facilities. Due to this restriction, people are in a rush to go to retail stores to buy household needs as a precautionary measure and supplies at a later time (Rahman, 2020). As reported on the CNN.com page, Chairperson of the Crisis Center of the University of Indonesia, Dicky Palupessy, stated that the panic buying phenomenon hit the public because the anxiety triggered it due to the outbreak of Covid-19. It was also caused by the lack of information received by the public regarding Covid-19. The phenomena of panic buying have either positive or negative impacts. The Ministry of Cooperatives and SMEs, Teten Masduki, said several sectors benefited from this pandemic. The increase in the purchase of staples jumps to 350\% (Indraini, 2020). However, this increase was accompanied by other negative impacts, namely rising prices, scarcity of goods, and speculators of individual elements of the community.

Consumers' anxiety during this pandemic shows that there is an intensity of society to meet product supplies due to fear and uncertainty. Consumers buy products in large quantities intending to avoid supply shortages that may occur in the future. This does not only happen in Jakarta, but this also occurs in several areas such as the City of Surabaya and some other cities (Wahyudi \& Setiawan, 2020). Nicola et al. (2020) stated that the food sector, including food and retail distributors, is under pressure because of panic buying. This has raised some concerns about food products. Therefore, it can be concluded that the phenomena of panic buying become the part of consumers' behavior caused by personal (psychological) and environmental factors that influence purchasing decisions.

Limitation of social activities during a pandemic has affected various business sectors and the economy. One of the most affected business sectors is the retail business. Like the existence of a modern market-type retail store, one sells and provides all kinds of basic daily needs (Hidayatullah \& Pandamsari, 2020). This type of retail store's existence answers the needs of residents who cannot go to traditional markets due to PSBB or concerns about being exposed to Covid-19. Based on DBS Group data, until 2019, most Indonesians choose to shop at traditional markets, around $70 \%$, rather than modern needs such as minimarkets or supermarkets. About 23\% of residents choose to shop at mini markets and 7\% at supermarkets. However, the current condition encourages people who previously prefer to shop to switch to the nearest supermarket or mini market or those that can be reached with little effort. One reason is that modern markets such as mini markets or super markets have advantages such as convenience and ease of access, especially since most mini markets currently operate for up to 24 hours in strategic locations such as close to housing or villages. In mid-March, Hippindo Front Advisor Tutum Rahanta, said that crowds continued to occur amid the Covid-19 pandemic. This is because many people visit mini markets or super markets to buy basic necessities and support activities at home (Hidayatullah \& Pandamsari, 2020). 
The retail business needs to survive amid this uncertain situation where companies must adapt quickly, responsively, and sustainably. Shifting consumer behavior patterns must be able to be correctly understood by the company. One of them is the convenience of service, which is part of the service marketing mix aiming to reach the target marketer. When customers can easily and comfortably feel the benefits of a service, they tend to be more satisfied with the service, known as service convenience (Chang et al., 2010). These are the factors that are considered in consumer purchase decisions.

This study aims to analyze the effect of panic buying and service convenience on consumer purchase decisions in modern markets such as mini markets, supermarkets, and hypermarkets in Surabaya.

\section{Literature Review}

\section{Consumer Behavior}

According to Schiffman \& Wisenblit (2015), consumer behavior is a study of consumer actions while looking for, buying, using, evaluating, and disposing of products and services they hope will satisfy their needs. Consumer behavior also explains how individuals decide to use available resources, namely (time, money, and effort) for goods offered by marketers for sale (Schiffman \& Wisenblit, 2015). In a study conducted by András \& Tamás (2020), which was conducted as a result of Covid-19, it was explained that the threat of this virus caused an intense panic response to occur in March 2020. The majority of respondents in this study reported an increase in spending in the first week of this stage of the crisis. Furthermore, András \& Tamás (2020) stated that the threat of Covid-19 has a significant impact on the entire retail sector in Hungary due to changes in customer shopping behavior.

\section{Purchase Decision}

According to Kotler \& Keller (2013), Purchase decisions are part of consumer behavior, namely how individuals, groups, and organizations choose, buy, use, and how goods, services, ideas, or experiences satisfy their needs and desires. Widyastuti \& Alwani (2018) stated that consumers' personal and environmental aspects had influenced consumers' purchase behavior. During the pandemic of Covid-19, consumers' buying products were significantly affected by anticipatory anxiety since the price of goods increased, controlled by a group or media exposure (Roy et al., 2020). András \& Tamás (2020) found that $87 \%$ of people involved in the survey reported that they made extra purchases to increase the stock of certain product groups at home. Changing shopping behavior is reflected in the avoidance of different product ranges (András \& Tamás, 2020). In that case, purchase decisions are influenced by drastic environmental changes, which can pave the way to reduce and combat post-traumatic disruption in times of crisis or to combat pandemic-related fears.

\section{Panic Buying}

According to Lins \& Aquino (2020), panic buying is more often observed during crisis periods and disturbing events. Still, it is not only stress caused by these events but also personal crises. Panic buying appeared to respond to stress during the Covid-19 pandemic (Garfin et al., 2020). Panic buying is often seen during a pandemic or epidemic, which leads to a lack of resources. Media coverage of resource shortages and essential matters of daily life increases the tendency to panic buying (Roy et al., 2020). Researchers consider that panic buying does not only arise because of stress, but there are other explanations. However, only a few studies have examined or discussed the phenomenon of panic buying; among the research references, there is an article from Garfin et al. (2020), which describes stress as a trigger for panic buying. The article Tsao et al. (2019) makes a systematic model calculation of the sale of goods during a panic buying situation. Furthermore, an article by Bacon \& Corr (2020) explains that panic buying related to Covid-19 is an adaptive mall behavior due to psychological conflicts in individuals. Then in a study conducted by András \& Tamás (2020), which was 
conducted in Hungary regarding panic buying that occurred due to Covid-19 which explained that the threat of this virus caused an intensive panic response to occur in March 2020.

Ho et al. (2020) explain the problem of panic buying in Singapore that occurs after the disaster response status has increased; people buy goods to maintain food supplies. Arafat et al. (2020) answered the causes of panic buying from consumer behavior factors, namely the perception of scarcity of goods. This means that panic buying can occur because many people think that certain items will be scarce during an outbreak of disease. The anxiety on the broader community can lead to panic buying during the Covid-19 outbreak (Roy et al., 2020). In Covid-19, panic buying behavior occurs because people experience psychological conflicts between the desire to stay safe and the desire to live an everyday and pleasant life (Bacon \& Corr, 2020). Panic buying occurs when consumers buy products to anticipate price increases or product scarcity when or after a disaster occurs, regardless of whether the risk occurs or not. Longitudinal studies show that the stress response increases when there is an event that threatens physical and mental health over time (Garfin et al., 2020). The stress response can also increase help-seeking behavior that is unbalanced and inappropriate to do in response to an actual threat (Garfin et al., 2020).

\section{Service Convenience}

Service convenience where when customers can easily and comfortably feel the benefits of a service, they tend to be more satisfied with the service (Chang et al., 2010). Service convenience is also defined as one of the strategies of a company, or business actor to meet needs to minimize time and effort for consumers to get benefits (Sains et al., 2016). Besides that, service convenience is one-way companies can increase customer value (Sains et al., 2016). The findings also provide managerial insights that can save customers time and effort, including offering an acceptable level of service comfort and improving the service quality. Even service providers must realize the importance of convenience in transactions. Business actors certainly have to mobilize energy to train cashiers (Benoit et al., 2017).

\section{Relationship Between Variables}

\section{Panic Buying and Purchase Decision}

Based on the previously described literature findings, it can be concluded that consumer purchasing behavior is influenced by several factors, both internally and externally. This study aims to analyze the factors that influence purchasing decisions. The variables used in this study are the panic buying variable and service convenience. Where the panic buying variable is a factor that affects consumer purchasing behavior personally. Arafat et al. (2020) stated that Covid-19 has had huge impacts on the entire retail sector due to the changes in shopping behavior in society. András \& Tamás (2020) claimed that there is panic buying where people want to fulfill their basic needs by making extra purchases to increase stock in several types of products. Panic buying raises sudden, uncontrolled behavior, occurs in many people, such as during the Covid19 pandemic, shopping excessively caused by worries about something that will happen in the future (Shadiqi et al., 2020). The cause of panic buying from consumer behavior factors is the perception of scarcity of goods in feelings of discomfort and instability of a situation. Furthermore, in this study, variable panic buying is measured by several indicators, which include anticipatory anxiety, fear, group mentality, uncertainty, uncontrolled, wrong information, media exposure. So it can be hypothesized as follows:

H1: Panic buying has a positive effect on purchasing decisions

\section{Service Convenience and Purchase Decision}

Furthermore, purchase decisions can also be influenced by the service factors provided by retail stores. In this study, service factors can be measured using variable service convenience. The emergence of service providers 
is increasingly important for consumer convenience and traceability, such as increased comfort in stores to find products. Furthermore, service providers must mobilize personnel to train cashiers and minimize the time needed in the checkout process (Benoit et al., 2017). This variable is measured through indicators of the convenience of decision-making, the convenience of access, convenience of transactions, and benefits (Aagja et al., 2011).

H2: Service convenience has a positive effect on purchasing decisions

\section{Hypothesis Development}

The relationship between variable panic buying (X1), service convenience (X2), and purchase decision (Y) can be seen in Figure I.

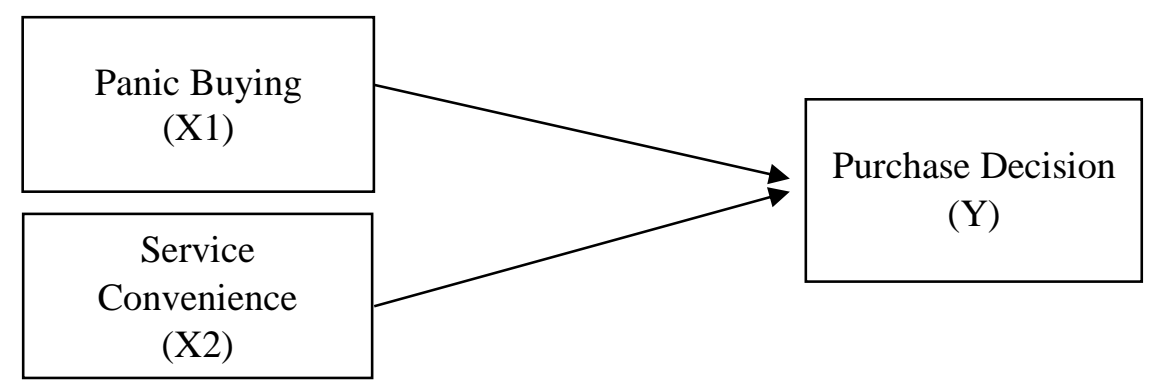

Figure 1 - Research Model

\section{Methodology}

This type of research uses a quantitative approach. The object of this research is consumers who shop at grocery stores during the Covid-19 pandemic between March and June 2020 in the city of Surabaya, East Java, Indonesia. The sampling technique in this study is non-probability sampling with the type of judgmental sampling in which the sample is selected based on the researcher's assessment as following the criteria determined by the researcher. (Malhotra, 2016). The researcher used 84 respondents as the sample. Based on the rule of thumb for sample size, according to Roscoe (1975), it states that sample sizes greater than 30 and less than 500 are appropriate for most studies conducted (Sekaran \& Bougie, 2016).

For convenience in data collection, the process was done through online-based questionnaires. Questionnaires were created via google form and were spread out through online social media such as Email, Instagram, and WhatsApp. The questionnaire later contains questions according to the research indicators and is measured using a 5-point Likert scale ranging from 1 strongly disagree to 5 strongly agree. Multiple linear regression analysis with the help of SPSS 23.0 software was used to analyze the research data. The characteristics of the respondents in this study were men and women aged 18-56 years, buying daily necessities in modern markets such as Hypermart, Indomaret, Alfamart, and others.

\section{Results}

\section{Descriptive Frequency Statistics}

Table 1 shows that female respondents account for $75 \%$ of the total number of respondents. The majority of these respondents were aged 18-27 years, as much as 95\%. According to the survey, $69 \%$ of respondents visited the Indomaret modern market. 
Table 1: Descriptive Frequency Statistics

\begin{tabular}{llcc}
\hline Variable & & Frequency & Percentage \\
\hline Gender & Male & 21 & $25 \%$ \\
Age & Female & 63 & $75 \%$ \\
& $18-27$ & 80 & $95 \%$ \\
& $28-37$ & 3 & $3.6 \%$ \\
Modern market & $38-47$ & 1 & $1.2 \%$ \\
& $48-57$ & 1 & $1.2 \%$ \\
& Alfamart & 19 & $22.6 \%$ \\
& Giant & 2 & $2.4 \%$ \\
& Hypermart & 3 & $3.6 \%$ \\
& Indomaret & 58 & $69 \%$ \\
\hline
\end{tabular}

\section{Construct Validity}

Table 2 provides the results for the validity stated that all variables are valid because they have a value R-count greater than the R-table for each variable.

Table 2: Validity and Test Result

\begin{tabular}{|c|c|c|c|c|}
\hline Variable & Items & R-count & R-table & Status \\
\hline & X1.1 & 0.684 & 0.361 & Valid \\
\hline & $\mathrm{X} 1.2$ & 0.749 & 0.361 & Valid \\
\hline & $\mathrm{X} 1.3$ & 0.772 & 0.361 & Valid \\
\hline & X1.4 & 0.786 & 0.361 & Valid \\
\hline & X1.5 & 0.785 & 0.361 & Valid \\
\hline Panic Buying & X1.6 & 0.729 & 0.361 & Valid \\
\hline \multirow{8}{*}{$(\mathrm{X} 1)$} & X1.7 & 0.605 & 0.361 & Valid \\
\hline & X1.8 & 0.599 & 0.361 & Valid \\
\hline & X1.9 & 0.625 & 0.361 & Valid \\
\hline & $\mathrm{X} 1.10$ & 0.630 & 0.361 & Valid \\
\hline & $\mathrm{X} 1.11$ & 0.789 & 0.361 & Valid \\
\hline & $\mathrm{X} 1.12$ & 0.350 & 0.361 & Valid \\
\hline & X2.1 & 0.771 & 0.361 & Valid \\
\hline & X2.2 & 0.665 & 0.361 & Valid \\
\hline Service & $\mathrm{X} 2.3$ & 0.806 & 0.361 & Valid \\
\hline Convenience & X2.4 & 0.812 & 0.361 & Valid \\
\hline \multirow[t]{10}{*}{ (X2) } & $\mathrm{X} 2.5$ & 0.643 & 0.361 & Valid \\
\hline & X2.6 & 0.777 & 0.361 & Valid \\
\hline & $\mathrm{X} 2.7$ & 0.729 & 0.361 & Valid \\
\hline & $\mathrm{X} 2.8$ & 0.804 & 0.361 & Valid \\
\hline & X2.9 & 0.771 & 0.361 & Valid \\
\hline & $\mathrm{X} 2.10$ & 0.561 & 0.361 & Valid \\
\hline & $\mathrm{X} 2.11$ & 0.607 & 0.361 & Valid \\
\hline & Y1.1 & 0.740 & 0.361 & Valid \\
\hline & Y1.2 & 0.722 & 0.361 & Valid \\
\hline & Y1.3 & 0.723 & 0.361 & Valid \\
\hline Purchase & Y1.4 & 0.632 & 0.361 & Valid \\
\hline
\end{tabular}




\begin{tabular}{lcccc}
\hline Decision & Y1.5 & 0.716 & 0.361 & Valid \\
$($ Y) & Y1.6 & 0.536 & 0.361 & Valid \\
& Y1.7 & 0.555 & 0.361 & Valid \\
& Y1.8 & 0.579 & 0.361 & Valid \\
& Y1.9 & 0.519 & 0.361 & Valid \\
\hline
\end{tabular}

\section{Reliability and Test Result}

The reliability test results in Table 3 show that all constructs have a value of more than 0.70 . Thus, all measurement models used in this study already have high reliability.

Table 3: Reliability and Test Result

\begin{tabular}{lccc}
\hline Variable & Cronbach's Alpha & Standard Deviation & Status \\
\hline X1 & 0.894 & 0.892 & Reliable \\
X2 & 0.898 & 0.910 & Reliable \\
Y & 0.816 & 0.832 & Reliable \\
\hline
\end{tabular}

\section{Multiple Regression Analysis Result}

Table 4 presents information on multiple regression analysis results, along with the explanation.

Table 4: Multiple Regression Analysis Result

\begin{tabular}{lc}
\hline Model & Unstandardized Coefficients B \\
\hline (Constant) & 7.707 \\
Panic Buying (X1) & 0.191 \\
Service Convenience (X2) & 0.541 \\
\hline
\end{tabular}

$\mathrm{Y}=7.707+0.191 \mathrm{X} \_1+0.541$ 【X】_2+e

The explanation of this equation is:

1. Constant (a) of 7.707 shows the purchase decision value. This means that if all are independent. If the variable is equal to zero $(0)$, the purchase decision $(\mathrm{Y})$ value is predicted to be 7.707.

2. The coefficient value of 0.191 means that if there is an increase in one unit of panic buying (X1), the purchase decision $(\mathrm{Y})$ will increase by 0.191 , assuming other variables are constant.

3. The coefficient value of 0.541 means that if there is an increase of one unit in service convenience (X2), then purchase decision (Y) will increase by 0.541 , assuming other variables are constant.

\section{F-Test Result ANOVA}

Table 5 shows that the F-value is 50.177 with a significance level of 0.000 (less than $5 \%$ ). So it can be concluded that $\mathrm{H} 1$ and $\mathrm{H} 2$ are accepted, which means that simultaneously there is an effect of panic buying and service convenience on the purchase decision.

Table 5: F-Test Result ANOVA

\begin{tabular}{|c|c|c|c|c|c|c|}
\hline \multicolumn{2}{|c|}{ Model } & Sum of Squares & df & Mean Square & F & Sig. \\
\hline 1 & Regression & 1548.163 & 2 & 774.082 & 50.177 & $.000^{\mathrm{b}}$ \\
\hline & Residual & 1249.587 & 81 & 15.427 & & \\
\hline & Total & 2797.750 & 83 & & & \\
\hline
\end{tabular}
a. Dependent Variable: Total_Y
b. Predictors: (Constant), Total_X2, Total_X1 


\section{T-Test Result Coefficients}

Table 6 presents the information on the T-Test result Coefficients, following the explanation.

Table 6: T-Test Result Coefficients

\begin{tabular}{|c|c|c|c|c|c|c|c|c|}
\hline \multirow{2}{*}{\multicolumn{2}{|c|}{ Model }} & \multicolumn{2}{|c|}{$\begin{array}{l}\text { Unstandardized } \\
\text { Coefficients }\end{array}$} & \multirow{2}{*}{$\begin{array}{c}\text { Standardized } \\
\text { Coefficients }\end{array}$} & \multirow[t]{2}{*}{$t$} & \multirow[t]{2}{*}{ Sig. } & \multicolumn{2}{|c|}{$\begin{array}{l}\text { Collinearity } \\
\text { Statistics }\end{array}$} \\
\hline & & B & Std. Error & & & & Tolerance & VIF \\
\hline 1 & (Constant) & 7.707 & 3.130 & & 2.462 & .016 & & \\
\hline & Total_X1 & .191 & .050 & .304 & 3.814 & .000 & .870 & 1.149 \\
\hline & Total X2 & .541 & .074 & .578 & 7.267 & .000 & .870 & 1.149 \\
\hline
\end{tabular}

a. Dependent Variable: Total_Y

Based on Table 6, by observing the rows, columns $t$ and sig can be explained as follows:

1. The effect of panic buying variables on purchase decision Variable panic buying (X1) has a positive and significant effect on consumer purchasing decisions in modern markets in the atmosphere of the Covid-19 pandemic. This can be seen from the significance of the panic buying variable of 0.000 , where $<0.05$. Furthermore, the $\mathrm{t}$-table value $=\mathrm{t}(\alpha / 2 ; \mathrm{n}-\mathrm{k}-1=\mathrm{t}(0,05 / 2 ; 84-2-1)$ $=(0.025 ; 81)=1.98969$. It means that the value of $\mathrm{t}$ is greater than the $\mathrm{t}$-table $(3.814>1.98969)$, then $\mathrm{H} 1$ is supported. So that panic buying has a positive effect on consumer purchasing decisions in modern markets in the atmosphere of the Covid-19 pandemic.

2. Effect of service convenience variables on purchase decision Service convenience (X2) has a positive and significant effect on consumer purchasing decisions in modern markets in the atmosphere of the Covid-19 pandemic. This can be seen from the significance of the service convenience variable of 0.000 , where $<0.05$. Furthermore, the t-table value $=\mathrm{t}(\alpha / 2 ; \mathrm{n}-\mathrm{k}-1=\mathrm{t}$ $(0.05 / 2 ; 84-2-1)=(0.025 ; 81)=1.98969$. It means that the value of $t$ is greater than the $t$-table $(7.268>1.98969)$, then $\mathrm{H} 2$ is supported. So that service convenience has a positive effect on consumer purchasing decisions in modern markets in the atmosphere of the Covid-19 pandemic.

\section{Discussion}

After collecting and analyzing data consecutively, the researchers concluded that all existing $\mathrm{H} 1$ and $\mathrm{H} 2$ were valid and showed a significant positive relationship between panic buying, service convenience, and consumer purchasing decision behavior. The results of this study are the same as the research conducted by András \& Tamás (2020) and Ho et al. (2020), who stated that panic buying occurred due to the Covid-19 pandemic encouraged people to make purchases to meet their daily needs. Furthermore, the results noted that the modern market must understand the community's situation and conditions and keep up with the latest crisis surrounding customers' needs, as is the case in this study, with the current covid-19 pandemic causing public panic about the little necessities of life, especially from March to June 2020 which causes consumer purchases of necessities of life to increase due to the discomfort caused by the Covid-19 pandemic. Consumers' convenience from service also impacts consumer purchasing decisions, especially in the current Covid-19 pandemic, where basic needs are needed, especially in modern markets where consumers are the primary choice a place to go to make purchases. The services provided are exemplary, speed in serving, product availability, warranty, product-related information is very needed by consumers, and creates its comfort in services that consumers feel, such as research conducted by Chang et al. (2010) and Benoit et al. (2017).

The findings in this research summarized that panic buying is part of consumer behavior caused by personal (psychological) and environmental factors that influence purchase decisions during the pandemic in the modern 
market, such as anticipating price increases, anticipating shortages of staples, news related to the pandemic of covid-19, seeing other people making purchases, uncertainty about product availability, etc. and the convenience of services provided by the modern market have led to purchase decision behavior such as strategic modern market locations, competitive product prices, adequate operating hours, convenience in making transactions, clear product information, and so on.

\section{Conclusion}

Purchasing decisions are the part of consumer behavior where it will significantly affect the success rate of goods and services. Panic buying and service convenience have become significant concerns in terms of purchasing decisions, especially in the era of the Covid-19 pandemic nowadays. This study examined the effect of panic buying and service convenience on buying decisions. The results showed that panic buying and service convenience partially had a positive impact on purchasing decisions. Also, it was found that simultaneously panic buying and service convenience also had positive effects on purchasing decisions.

\section{Limitations}

This study focuses on panic buying and service convenience on consumer purchasing decisions during the Covid-19 pandemic. The respondents were 18-56 years old. The samples taken are only respondents who have made purchases in modern markets such as Indomaret, Alfamart, hypermart, etc., in Surabaya. This research was conducted because of the Covid-19 pandemic current situation. In the future, it is also expected to conduct research using other variables that connect to the phenomenon of Covid-19.

Funding: This research received no external funding.

Acknowledgments: The author would like to thank all respondents who were willing to participate in this research.

Conflicts of Interest: The authors declare no conflict of interest.

\section{References}

Aagja, J. P., Mammen, T., \& Saraswat, A. (2011). Validating service convenience scale and profiling customers: A study in the indian retail context. Vikalpa, 36(4), 25-49. https://doi.org/10.1177/0256090920110403

András, K., \& Tamás, S. T. (2020). Panic buying in Hungary during Covid-19 Disease. 21(1), 1-9. https://doi.org/10.13140/RG.2.2.21264.76800

Arafat, S. M. Y., Kar, S. K., Marthoenis, M., Sharma, P., Hoque Apu, E., \& Kabir, R. (2020). Psychological underpinning of panic buying during pandemic (Covid-19). Psychiatry Research, 289(May), 113061. https://doi.org/10.1016/j.psychres.2020.113061

Bacon, A. M., \& Corr, P. J. (2020). Coronavirus (Covid-19) in the United Kingdom: A personality-based perspective on concerns and intention to self-isolate. British Journal of Health Psychology, 25(4), 839_ 848. https://doi.org/10.1111/bjhp.12423

Benoit, S., Klose, S., \& Ettinger, A. (2017). Linking service convenience to satisfaction: dimensions and key moderators. Journal of Services Marketing, 31(6), 527-538. https://doi.org/10.1108/JSM-10-20160353

Chang, K. C., Chen, M. C., Hsu, C. L., \& Kuo, N. Te. (2010). The effect of service convenience on postpurchasing behaviours. Industrial Management and Data Systems, 110(9), 1420-1443. https://doi.org/10.1108/02635571011087464

Garfin, D. R., Silver, R. C., \& Holman, E. A. (2020). The novel coronavirus (Covid-2019) outbreak: Amplification of public health consequences by media exposure. Health Psychology, 39(5), 355-357. https://doi.org/10.1037/hea0000875 
Hidayatullah, T., \& Pandamsari, A. P. (2020). Berkah untuk minimarket di tengah pandemi Covid-19. Lokadata.Id. https://lokadata.id/artikel/berkah-minimarket-di-tengah-pandemi-covid-19

Ho, C. S., Chee, C. Y., \& Ho, R. C. (2020). Mental Health Strategies to Combat the Psychological Impact of COVID-19 Beyond Paranoia and Panic. Annals of the Academy of Medicine, Singapore, 49(1), 1-3.

Indraini, A. (2020). Panic Buying Nyata, Corona Bikin Pembelian Bahan Pokok Naik 350\%. Detikfinance. https:/ finance.detik.com/berita-ekonomi-bisnis/d-4994694/panic-buying-nyata-corona-bikinpembelian-bahan-pokok-naik-350

Kotler, P., \& Keller, K. L. (2013). Marketing Management. In Marketing Management. https://doi.org/10.4324/9780203357262

Lins, S., \& Aquino, S. (2020). Development and initial psychometric properties of a panic buying scale during Covid-19 pandemic. Heliyon, 6(9), e04746. https://doi.org/10.1016/j.heliyon.2020.e04746

Malhotra, N. K. S. D. (2016). Marketing Research An Applied Orientation (seventh). pearson.

Nicola, M., Alsafi, Z., Sohrabi, C., Kerwan, A., Al-Jabir, A., Iosifidis, C., Agha, M., \& Agha, R. (2020). The socio-economic implications of the coronavirus pandemic (Covid-19): A review. International Journal of Surgery, 78(April), 185-193. https://doi.org/10.1016/j.ijsu.2020.04.018

Pemerintah Indonesia. (2020). Pembatasan Sosial Berskala Besar dalam Rangka Percepatan Penanganan Corona Virus Disease 2019 (Covid-19). JDIH, https://peraturan.bpk.go.id/Home/Details/135059/pp-no-21-tahun-2020

Putra, N. P. (2020). Virus Corona Picu Panic Buying Makanan, Masker, Hand Sanitizer, Bagaimana Meredamnya? Liputan6.Com. https://www.liputan6.com/news/read/4193886/headline-viruscorona-picu-panic-buying-makanan-masker-hand-sanitizer-bagaimana-meredamnya

Rahman, R. (2020). Alasan Psikologi di Balik "Panic Buying." CNN Indonesia. https://www.cnnindonesia.com/gaya-hidup/20200322161747-284-485813/alasan-psikologi-di-balikpanic-buying

Roy, D., Tripathy, S., Kar, S. K., Sharma, N., Verma, S. K., \& Kaushal, V. (2020). Study of knowledge, attitude, anxiety \& perceived mental healthcare need in Indian population during Covid-19 pandemic. Asian Journal of Psychiatry, 51(April), 102083. https://doi.org/10.1016/j.ajp.2020.102083

Sains, J., Indonesia, P., Soesanto, H., \& Sufian, S. (2016). Studi Mengenai Keputusan Pembelian Dengan Pendekatan Service Encounter, Service Convenience Dan Product Knowledge Yang Dimediasi Oleh Purchase Intention Pada Bengkel Pt. Astra International-Daihatsu Sales Operation Semarang. Jurnal Sains Pemasaran Indonesia, 15(02), 93-106. https://doi.org/10.14710/jspi.v15i02.93-106

Schiffman, L. G., \& Wisenblit, J. L. (2015). Consumer Behavior, Eleventh Edition. In Consumer Behavior (Issue 6).

Sekaran, U., \& Bougie, R. (2016). Research methods for business : a skill-building approach / Uma Sekaran and Roger Bougie. In Library of Congress cataloging-in-Publication Data (Seventh ed). Chichester, West Sussex, United Kingdom : John Wiley \& Sons. https://doi.org/10.1007/978-94-007-0753-5_102084

Shadiqi, M. A., Hariati, R., Fadhli, K., Hasan, A., Noor, I., \& Istiqomah, W. Al. (2020). Early View Panic buying pada pandemi Covid-19: Telaah literatur dari perspektif psikologi. 18(xx). https://doi.org/10.7454/jps.2020.xx

Thukral, N. (2020). Panic Buying, Lockdowns May Drive World Food Inflation - FAO, Analysts. Usnews.Com. https://www.usnews.com/news/world/articles/2020-03-21/panic-buying-lockdowns-may-driveworld-food-inflation-fao-analysts

Tsao, Y. C., Raj, P. V. R. P., \& Yu, V. (2019). Product substitution in different weights and brands considering customer segmentation and panic buying behavior. Industrial Marketing Management, 77(September), 209-220. https://doi.org/10.1016/j.indmarman.2018.09.004

Wahyudi, E., \& Setiawan, K. (2020). Aprindo Sebut Panic Buying di 6 Kota Pasca Pengumuman Corona. Tempo.Co. https://bisnis.tempo.co/read/1315098/aprindo-sebut-panic-buying-di-6-kota-pasca- 
pengumuman-corona $/$ full\&view $=\mathrm{ok}$

Widyastuti, P., \& Alwani, A. (2018). Peran Community Advice Sebagai Pemoderasi Dalam Keputusan Pembelian. Jurnal Manajemen Dan Pemasaran Jasa, 11(1), 67. https://doi.org/10.25105/jmpj.v11i1.2496 